\title{
IAMJ
}

INTERNATIONAL

AYURVEDIC

MEDICAL JOURNAL

Research Article

ISSN: 23205091

Impact Factor: 5.344

\section{A COMPARATIVE CLINICAL STUDY TO EVALUATE THE EFFICACY OF SANKHA- PUSHPI CHOORNA WITH SAHAPANA OF KSHEERA AND DRAKSHA SWARASA IN NIDRANASHA W.S.R.TO PRIMARY INSOMNIA}

\author{
Sabeena Susmitha A. K' ${ }^{1}$, Zenica D'souza ${ }^{2}$ \\ ${ }^{1}$ Final Year PG Scholar, ${ }^{2}$ Professor \& HOD; \\ Department of Kayachikitsa, Alva's Ayurveda Medical College, Mooodbidri, Karnataka, India
}

Corresponding Author: susmi111@gmail.com

\section{https://doi.org/10.46607/iamj0508082020}

(Published online: August 2020)

Open Access

(C) International Ayurvedic Medical Journal, India 2020

Article Received: 11/07/2020 - Peer Reviewed: 01/08/2020 - Accepted for Publication: 03/08/2020

Check for updates

\footnotetext{
ABSTRACT

Background: Sleep has occupied a special place in human concern. It has been rightly stated by Acharya Charaka that happiness and misery, proper and improper growth, good strength and weakness, potency and sterility, knowledge and ignorance, life and death of an individual depend on the quality of sleep. The condition of Insomnia has tendency to damage the person's daily life, including his social and occupational life. Considering this Sankhapushpi Choorna with Go ksheera and Draksha Swarasa were selected for this study. Sankhapushpi Choorna has the property of Nidrajanana and Medhya. Ksheera has the property of VataPitta Shamana and Draksha has the property of Pitta Kapha Shamana, Rakta Prasadana.

Methods: The study was Randomized parallel Group comparison clinical study. The study was conducted in 60 subjects for a period of 30 days. Subjective and objective parameters were documented at base line, $7^{\text {th }}$ day, $15^{\text {th }}$ day and on $30^{\text {th }}$ day. Observations were analysed and findings were evaluated by using statistical methods.

Results: This study shows that both Sankhapushpi Choorna with Ksheera and Sankhapushpi Choorna with Draksha Swarasa have significant effect in Nidranasha.

Conclusion: The result obtained was both Sankhapushpi Choorna with Ksheera and Sankhapushpi Choorna with Draksha Swarasa have significant effect in Nidranasha. There is no significant difference in effect of Sankhapushpi Choorna with Ksheera and Sankhapushpi Choorna with Draksha Swarasa.
} 
Keywords: Sankhapushpi Choorna, Ksheera, Draksha, Nidranasha, Sahapana, Primary Insomnia

\section{INTRODUCTION}

Nidra is one among the Trayopastambha in Ayurveda and supports the wellbeing of an individual. Sleep disorders are increasing day by day for various reasons related to lifestyle and profession. In India Insomnia has a prevalence of $10 \%-48 \%$ in the general population of which $18.6 \%$ was reported in South India ${ }^{1}$. Primary Insomnia is associated with substantial impairment in an individual's quality of life, impacting health, work and healthcare cost. Insomnia left untreated may reduce the mental and physical efficiency and drag the individual towards several psycho-somatic disorders. Nidranasha is caused by aggravated Vayu, Pitta, an aggrieved state of the mind, wasting of Dhatu, and trauma ${ }^{2}$. Contemporary management for Insomnia is mainly by tranquilizers, anti-depressants, sedatives and hypnotics. Long term use of these may cause various side effects including drug dependency. Sankhpushpi is having the properties such as Tikta Rasa, Snigdha, Picchila Guna, Sheeta Virya, Pitta Kapha Hara, and has the Karma as Nidrajanana, Moha Nashaka, Rasayana and Medhya . Go ksheera ${ }^{5}$ and Draksha ${ }^{6}$ are also having the propertirs of Nidrajanana. Having Madhurarasa, Mridu, Snigdhaguna, Sheeta Virya and Vata Pitta Shamaka properties $^{7}$ and Madhura Rasa, Guru, Snigdha, MriduGuna, Seeta Virya, Vata Pitta Shamaka properties and Karma as Rakta Prasadana, Dourbalya Nashaka and Balya respectively. Sahapana refers to a Dravya taken along with the medicine, which enables the medicine to get absorbed into the body and spread its action quickly all over the body ${ }^{8}$.

\section{Materials and Methods}

\section{Objectives of the study}

1. To evaluate the efficacy of Sanhkapushpi Choorna with Ksheera in Nidranasha

2. To evaluate the efficacy of Sankhapushpi Choorna with Draksha Swarasa in Nidranasha

3. To compare the efficacy of Sankhapushpi Choorna with Ksheera and Sankhapushpi Choorna with Draksha Swarasa in Nidranasha

\section{Source of Data}

Sample Source: People suffering from Nidranasha visiting OPD and IPD of Kayachikitsa of Alva's Ayurveda Medical College Hospital, Moodbidri.

Drug Source: Raw drugs collected from the source of procurement and identified by experts concerned.

Sankhapushpi (whole plant) Choorna prepared at Alva's Pharmacy, Mijar, Moodbidri.

Method of sampling: LotteryMethod. Patients diagnosed with Nidranasha were randomly allocated into two groups A and B.

\section{Criteria For Selection Of Patients}

Diagnostic criteria: Diagnosis made according to the guidelines mentioned in ICD-109.

1. A complaint of difficulty falling asleep, maintaining sleep, or non-refreshing sleep.

2. The sleep disturbance occurs at least three times per week for at least one month.

3. The sleep disturbance results in marked personal distress or interference with personal functioning in daily living.

4. Absence of any known causative organic factor, such as neurological or other medical condition, psycho active substance use disorder or a medication.

Inclusion Criteria: Patients having Lakshana of Nidranasha and Patients between 16- 60 years of age.

Exclusion Criteria: Insomnia secondary to Major mental disorders, Pregnant Women and Lactating Mothers, Insomnia caused by other Medical conditions. Study Design: Randomized parallel Group comparison clinical study.

Intervention: Group A - Participants were given with $3 \mathrm{~g}$ of Sankhapushpi Choorna with 50ml of Ksheera at night after food for 14 days. Group B - Participants were given with $3 \mathrm{~g}$ of Sankhapushpi Choorna with $50 \mathrm{ml}$ of Draksha Swarasa at night after food for 14 days.

Observation Period: Patients were assessed with Subjective and objective parameters at baseline and on $7^{\text {th }}$ 
day during treatment and on $15^{\text {th }}$ day after treatment and follow up was on $30^{\text {th }}$ day. Total study duration was 30 days.

Assessment Criteria: Primary outcomes were Angamarda, Shirogourava, Jrumbha, Jadya, Glani, Bhrama and Apakti. Secondary outcomes were the criteria mentioned in Athens Insomnia Scale.

\section{Results}

There were 60 patients of Nidranasha registered for the study and were randomly allocated into two groups A\&B. Group A had 30 patients and Group B had 30 patients. Totally 60 patients completed the clinical trial. In Group A, 30 Patients were given with Sankhapushpi Choorna with Ksheera and Group B, 30 patients were given Sankhapushpi Choorna with Draksha Swarasa. Summary statistics have been interpreted for S.D, SE, MD, MEAN, t-value, $p$-value. Test of results within the group by using paired t-test and between the groups by using unpaired t-test. Subjective parameters that assessed for the study were Angamarda, Shirogourava, Jrumbha, Jadya, Glani, Bhrama and Apakti. Objective parameters that taken for assessment were Sleep induction, Awakening during night, Final awakening, Total sleep duration, Sleep quality, Wellbeing during the day, Functioning capacity during the day and Sleepiness during the day. Both the individual effect of parameters on baseline, $7^{\text {th }}$ day, $15^{\text {th }}$ day and $30^{\text {th }}$ day in Group A and B were compared. Effect of Sankhapushpi Choorna with Ksheera and Sankhapushpi Choorna with Draksha Swarasa on Subjective Parameters were analyzed statistically, difference was significant at the level of ( $\mathrm{p}=<0.001)$. (Table No.1). Effect of Sankhapushpi Choorna with Ksheera and Sankhapushpi Choorna with Draksha Swarasa on Athens Insomnia Scale were analyzed statistically, difference was significant at the level of $(\mathrm{p}=<0.001)$ (Table No.2). While comparing both groups on Subjective parameters Angamarda, jrumbha and jaadya shows significant values and all other parameters shows insignificant results. (Table No.3). While comparing both groups on Athens Insomnia Scale shows insignificant result with p value 0.65. (Table No.4)

\section{DISCUSSION}

\section{Discussion on Observation}

Gender Incidence: Majority of patients were female i.e.58.3\%. The production of various neuro-endocrinal hormones differs in female during puberty, menstrual cycles, pregnancy, and menopause. The shifting of ratios of hormones can be an unsettling process, this contributing to the inability to fall asleep.

Age: All the patients in this series were between the age of 16 to 60 years. This study shows $46.6 \%$ subjects from 16-30 age group, 30\% were 31-45 age group and $23.3 \%$ subjects from $46-60$ age group. It showed that primary insomnia is common in older adults due to certain biological changes like shift in circadian rhythm that make sleep more difficult as we age.

Religion: In this study $48.3 \%$ of the patients were Hindus. It does not mean that Hindus are more prone to this disease, this may be due to the fact that the area had more Hindus, and the patients were elected incidentally.

Occupation: In this series maximum no. of patients $(21.6 \%)$ were housewives and IT professionals- Maybe middle-aged women are having more stress because of nearing to the Menopause. And IT professionals having more stress over work.

Socio economic status: Primary Insomnia has been considered a disease of the intelligent and middle social class, because of the stress. But higher classes and lower-class people are not exposing to mental stress as much. Middle class people do hard mental work. So, it is more common in middle social class.

Marital status: $81.6 \%$ of patients were married, it shows that due to family problem and stress in working field may lead to the condition of primary insomnia in them.

Addiction: Clinical study shows that $50 \%$ of patients were addicted to Tea/Coffee. Caffeine is an alkaloid which is present in coffee and tea which has a stimulant action on CNS and increased mental activity, thereby causing reduced sleep.

Prakriti: The Deha Prakriti of the patients suffering from primary insomnia was assessed, based on the physical, psychological and behavioral factors mentioned in Ayurvedic classics. In this study maximum 
patients belong to Vatapitta Prakriti. This is obvious as Nidranasha is caused due to Vata vitiation. And also, it is revealed that the majority of patients has Rajasika Prakriti followed Rajasika satvika property.

Chronicity: Majority of the patients were having chronicity ranging from 6 months to 1year may be due to lack of sleep hygiene.

Dietary habits: $91.6 \%$ patients of this series were mixed dietarians and remaining $8.6 \%$ were vegetarianas a greater number of patients are from costal belt and their dietary habit is mixed.

Specific Hetu: Out of 60 patients, specific Hetu of Nidranasha was Chinta which was observed in $25 \%$ of patients. As Chinta is said to be the direct cause for Nidranasha as they provoke Raja, Vata, Pitta and decreases Satva, Tama and Kapha and cause Nidranasha. Chinta or stress activates the HPA system, activation of HPA and/ or the sympathetic nervous system results in wakefulness and these hormones including Corticotropin-releasing hormone (CRH), Adreno corticotropic hormone (ACTH), Cortisolor Corticosterone, Noradrenaline and Adrenaline are associated with attention and arousal.

\section{Discussion on Result}

In the clinical trial the given drug Group A and B (the interventions done in group A and B) had very good response in relieving the symptoms, which were also statistically significant. Both Sankhapushpi Choorna with Ksheera and Sankhapushpi choorna with Draksha swarasa showed statistically significant difference in all the assessment criteria. Further it was accepted that, there was no significant statistical difference in the effect of Sanhkapushpi Choorna with Ksheera and Sanhkapushpi Choorna with Draksha swarasa in Nidranasha.

On comparison between 2 groups in assessment criteria there was statistical difference seen for Angamarda, Jrumbha and Jaadya. All other subjective and Objective parameters showed no statistically significant difference between the groups.

\section{Probable mode of action of Drugs}

Sankhapushpi: Rasa of Sankhapushpi i Tikta Rasa with Snigdha, Picchila guna, Sheeta Virya and Madhura Vipaka. Main chemical constituent is
Alkaloids contains-convolamine, convoline, phyllabine, convoline, convosine, Convolvine, confoline, convolvidine, sankhapushpine, $\beta$-sitosterol, Scopoletin, kaempferol, N-hexacosanol, Hydroxy cinnamic acid. Also, volatile oils, Fatty acids, fatty alcohols, hydrocarbons, myristic acids, palmitic acids and linoleic acids are found. The flavonoids, glycosides and alkaloids help soothe our nervous system by bringing relief to mental fatigue. Thiopental sodium present in the sankhapushpi also may contribute for inducing sleep.

Milk: It contains amino acid known as tryptophan which help to induce sleep. Milk also contains melatonin, a hormone that regulate the sleep wake cycle.

Draksha: Rasa of Draksha is Madhura Rasa with Guru, Snigda, Mridu guna, Sheeta Virya, and Madhura Vipaka. Madhura rasa helps in the shamana of Vata Dosha.

\section{CONCLUSION}

Nidranasha is included in 80 vata roga caused due to the morbidity of the Vata and Pitta Dosha and Mano Dosha Rajas involving Rasa Dhatu, commonly associated with Angamarda, Shirogaurava, Jrumbha, Jadya, Glani, Bhrama and Apakti. Both Sankhapushpi Choorna with Ksheera and Sankhapushpi Choorna with Draksha Swarasa showed statistically significant effect in all the criteria.

On comparison between the two groups post treatment with assessment criteria there is statistical difference only for Angamarda, Jrumbha, Jaadya. All other subjective and Objective parameters show statistically insignificant difference. Hence the conclusion drawn was, there was no significant difference in the effect of Sankhapushpi choorna with Ksheera and Sankhapushpi choorna with Draksha swarasa in Nidranasha.

\section{REFERENCES}

1. Harrison's Principles Of Internal Medicine, Volume 1,16th Edition, Edited By Eugen Braundwald, Anathony S Fanchi, Stephen L Hauser, Dennis L Kasper, Dan L Longo, J Larry Jameson, Published By Mcgraw Hill, Pg153.

2. Sushruta-Sushruta Samhita With Commentaries Nibandhasangraha Of Sri Dalhanacharya And Nyayachandrika Panjika Of Sri Gayadasacharya Edited By Vaidya 
Jadavji Trikamji Acharya Kavyatirtha, Chaukambha Sanskrit Sansthan, Varanasi,2012.

3. Acharya Parivruthasharma And Guruprasadasharma Kaiyadevanigantu (Pathyapathyavibodhika), Chaukamba Auriyantalia, Varanasi, $9^{\text {th }}$ Chapter, Pg.622.

4. Sushruta-Sushruta Samhita With Commentaries Nibandhasangraha Of Sri Dalhanacharya And Nyayachandrika Panjika Of Sri Gayadasacharya Edited By Vaidya Jadavji Trikamji Acharya Kavyatirtha, Chaukambha Sanskrit Sansthan, Varanasi, 2012.

5. Sushruta-Sushruta Samhita With Commentaries Nibandhasangraha Of Sri Dalhanacharya And Nyayachandrika Panjika Of Sri Gayadasacharya Edited By Vaidya Jadavji Trikamji Acharya Kavyatirtha, Chaukambha Sanskrit Sansthan, Varanasi, 2012.
6. Sushruta-Sushruta Samhita With Commentaries Nibandhasangraha Of Sri Dalhanacharya And Nyayachandrika Panjika Of Sri Gayadasacharya Edited By Vaidya Jadavji Trikamji Acharya Kavyatirtha, Chaukambha Sanskrit Sansthan, Varanasi,2012.

7. Sree Sadananda Sharma - Rasatharangini With The Commentary Prasadini, Rasavijnana Hindivyakya By Kasinatha Shastri, Motilal Banarasidas, Varanasi, Edition 2000; 6:143.

8. Http://Www.Who.Int// The ICD 10 Classification Of Mental \& Behavioral Disorders, Accessed On December 12-2015,9.30hrs.

9. Https://En.Wikipedia.Org/Wiki/Athens_Insomnia_Scale,Assessed On December 122015,9.30hrs

Table 1: Statistical Results For Subjective Parameters

\begin{tabular}{|c|c|c|c|c|c|c|c|c|c|}
\hline Parameters & Group & BT mean & DT & MD & $\%$ & S.D & S.E & $\mathrm{t}$ - value & $\mathrm{p}$-value \\
\hline \multirow[t]{6}{*}{ Angamarda } & \multirow[t]{3}{*}{ A } & \multirow[t]{3}{*}{2.33} & D7 & 0.77 & 33.04 & 0.43 & 0.07 & 9.76 & $<0.001$ \\
\hline & & & AT & 1.46 & 62.6 & 0.68 & 0.12 & 11.78 & $<0.001$ \\
\hline & & & $\mathrm{AF}$ & 2.07 & 88.8 & 1.04 & 0.19 & 10.79 & $<0.001$ \\
\hline & \multirow[t]{3}{*}{ B } & \multirow[t]{3}{*}{1.4} & D7 & 0.77 & 33.04 & 0.43 & 0.07 & 9.76 & $<0.001$ \\
\hline & & & AT & 1.46 & 62.6 & 0.68 & 0.12 & 11.78 & $<0.001$ \\
\hline & & & $\mathrm{AF}$ & 2.07 & 88.8 & 1.04 & 0.19 & 10.79 & $<0.001$ \\
\hline \multirow[t]{6}{*}{ Shirogourava } & \multirow[t]{3}{*}{ A } & \multirow[t]{3}{*}{2.4} & D7 & 0.83 & 34.58 & 0.37 & 0.06 & 12.04 & $<0.001$ \\
\hline & & & AT & 1.6 & 66.66 & 0.62 & 0.13 & 14.1 & $<0.001$ \\
\hline & & & $\mathrm{AF}$ & 2.16 & 90 & 0.87 & 0.16 & 13.57 & $<0.001$ \\
\hline & \multirow[t]{3}{*}{ B } & \multirow[t]{3}{*}{2.1} & D7 & 0.43 & 20.47 & 0.5 & 0.09 & 4.7 & $<0.001$ \\
\hline & & & AT & 1.3 & 61.9 & 0.59 & 0.1 & 11.94 & $<0.001$ \\
\hline & & & $\mathrm{AF}$ & 2.13 & & 0.77 & 0.14 & 15.05 & $<0.001$ \\
\hline \multirow[t]{6}{*}{ Jrumbha } & \multirow[t]{3}{*}{ A } & \multirow[t]{3}{*}{2.1} & D7 & 0.7 & 33.3 & 0.46 & 0.08 & 8.23 & $<0.001$ \\
\hline & & & AT & 1.37 & 65.23 & 0.8 & 0.15 & 9.25 & $<0.001$ \\
\hline & & & $\mathrm{AF}$ & 1.87 & 89.04 & 1.19 & 0.21 & 8.56 & $<0.001$ \\
\hline & \multirow[t]{3}{*}{ B } & \multirow[t]{3}{*}{0.87} & D7 & 0.2 & 22.9 & 0.4 & 0.07 & 2.69 & $<0.001$ \\
\hline & & & AT & 0.63 & 72.4 & 0.8 & 0.14 & 4.28 & $<0.001$ \\
\hline & & & $\mathrm{AF}$ & 0.8 & 91.9 & 0.99 & 0.18 & 4.39 & $<0.001$ \\
\hline \multirow[t]{6}{*}{ Jaadya } & \multirow[t]{3}{*}{ A } & \multirow[t]{3}{*}{2.13} & D7 & 0.76 & 35.6 & 0.43 & 0.07 & 9.76 & $<0.001$ \\
\hline & & & AT & 1.46 & 68.5 & 0.68 & 0.12 & 11.78 & $<0.001$ \\
\hline & & & $\mathrm{AF}$ & 1.9 & 89.2 & 1.02 & 0.18 & 10.11 & $<0.001$ \\
\hline & \multirow[t]{3}{*}{ B } & \multirow[t]{3}{*}{0.7} & D7 & 0.3 & 42.8 & 0.46 & 0.08 & 3.52 & $<0.001$ \\
\hline & & & AT & 0.66 & 94.2 & 0.66 & 0.12 & 5.52 & $<0.001$ \\
\hline & & & $\mathrm{AF}$ & 0.7 & 100 & 0 & 0 & 5.46 & $<0.001$ \\
\hline \multirow[t]{6}{*}{ Glani } & \multirow[t]{3}{*}{ A } & \multirow[t]{3}{*}{1.7} & D7 & 0.66 & 38.8 & 0.47 & 0.08 & 7.6 & $<0.001$ \\
\hline & & & AT & 1.13 & 66.4 & 0.86 & 0.15 & 7.21 & $<0.001$ \\
\hline & & & $\mathrm{AF}$ & 1.43 & 84.1 & 1.04 & 0.19 & 7.54 & $<0.001$ \\
\hline & \multirow[t]{3}{*}{ B } & \multirow[t]{3}{*}{0.9} & D7 & 0.13 & 14.4 & 0.34 & 0.06 & 2.11 & $<0.001$ \\
\hline & & & AT & 0.73 & 81.1 & 0.58 & 0.1 & 6.88 & $<0.001$ \\
\hline & & & $\mathrm{AF}$ & 0.9 & 100 & 0 & 0 & 6.92 & $<0.001$ \\
\hline \multirow[t]{4}{*}{ Bhrama } & \multirow[t]{3}{*}{ A } & 0.56 & D7 & 0.36 & 64.2 & 0.49 & 0.08 & 4.09 & $<0.001$ \\
\hline & & & AT & 0.53 & 94.6 & 0.68 & 0.12 & 4.28 & $<0.001$ \\
\hline & & & $\mathrm{AF}$ & 0.56 & 100 & 0.77 & 0.14 & 4.01 & $<0.001$ \\
\hline & B & 0.63 & D7 & 0.56 & 88.8 & 0.5 & 0.09 & 6.15 & $<0.001$ \\
\hline
\end{tabular}




\begin{tabular}{|c|c|c|c|c|c|c|c|c|c|}
\hline & & & AT & 0.63 & 100 & 0.49 & 0.08 & 7.07 & $<0.001$ \\
\hline & & & $\mathrm{AF}$ & 0.63 & 100 & 0.49 & 0.08 & 7.07 & $<0.001$ \\
\hline \multirow[t]{6}{*}{ Apakti } & \multirow[t]{3}{*}{ A } & \multirow[t]{3}{*}{1.43} & D7 & 0.46 & 32.1 & 0.5 & 0.09 & 5.03 & $<0.001$ \\
\hline & & & AT & 0.9 & 62.9 & 0.88 & 0.16 & 5.57 & $<0.001$ \\
\hline & & & $\mathrm{AF}$ & 1.26 & 88.1 & 1.31 & 0.23 & 5.29 & $<0.001$ \\
\hline & \multirow[t]{3}{*}{ B } & \multirow[t]{3}{*}{1.43} & D7 & 0.4 & 27.9 & 0.49 & 0.09 & 4.39 & $<0.001$ \\
\hline & & & AT & 0.93 & 65 & 0.78 & 0.14 & 6.51 & $<0.001$ \\
\hline & & & $\mathrm{AF}$ & 0.25 & 17.4 & 1.09 & 0.2 & 6.81 & $<0.001$ \\
\hline
\end{tabular}

Table 2: Statistical Results On Objective Parameters

\begin{tabular}{|c|c|c|c|c|c|c|c|c|c|}
\hline \multirow{2}{*}{$\begin{array}{l}\text { Assessment } \\
\text { criteria }\end{array}$} & \multicolumn{4}{|c|}{ Mean score } & $\%$ & \multirow[t]{2}{*}{ SD } & \multirow[t]{2}{*}{ SE } & \multirow[t]{2}{*}{$\mathrm{t}$ value } & \multirow[t]{2}{*}{$\mathrm{p}$ value } \\
\hline & BT & & & BT-AT & & & & & \\
\hline \multirow{3}{*}{$\begin{array}{l}\text { Athens in- } \\
\text { somnia scale }\end{array}$} & & DT-7 & 9.8 & 3.7 & 27.4 & 3.09 & 0.56 & 6.54 & $<0.001$ \\
\hline & 13.5 & AT-15 & 4.66 & 8.83 & 65.4 & 4.43 & 0.81 & 10.91 & $<0.001$ \\
\hline & & AF-30 & 0.9 & 12.6 & 93.33 & 5.32 & 0.97 & 12.95 & $<0.001$ \\
\hline
\end{tabular}

Table 3: Statistical Results While Comparing the Subjective Parameters

\begin{tabular}{|c|c|c|c|c|c|c|c|}
\hline \multirow[t]{2}{*}{ Parameters } & \multirow[t]{2}{*}{ Group } & \multirow[t]{2}{*}{ Mean } & \multirow[t]{2}{*}{$\mathrm{MD}$} & \multicolumn{4}{|c|}{ Unpaired $t$ test } \\
\hline & & & & S.D & S.E & $\mathrm{t}$ value & $\mathrm{p}$ value \\
\hline \multirow{2}{*}{ Angamarda } & Group A & 0.86 & \multirow{2}{*}{0.5} & 0.5 & 0.09 & \multirow[t]{2}{*}{3.63} & \multirow{2}{*}{$<0.001$} \\
\hline & Group B & 0.36 & & 0.55 & 0.1 & & \\
\hline \multirow[t]{2}{*}{ Shirogourava } & Group A & 0.8 & \multirow[t]{2}{*}{0.06} & 0.55 & 0.1 & \multirow[t]{2}{*}{0.52} & \multirow[t]{2}{*}{0.6} \\
\hline & Group B & 0.86 & & 0.43 & 0.07 & & \\
\hline \multirow[t]{2}{*}{ Jrumha } & Group A & 0.73 & \multirow[t]{2}{*}{0.5} & 0.52 & 0.09 & \multirow[t]{2}{*}{3.77} & \multirow[t]{2}{*}{$<0.001$} \\
\hline & Group B & 0.23 & & 0.5 & 0.09 & & \\
\hline \multirow[t]{2}{*}{ Jaadya } & Group A & 0.66 & \multirow[t]{2}{*}{0.63} & 0.54 & 0.09 & \multirow[t]{2}{*}{6.01} & \multirow[t]{2}{*}{$<0.001$} \\
\hline & Group B & 0.03 & & 0.18 & 0.03 & & \\
\hline \multirow[t]{2}{*}{ Glani } & Group A & 0.56 & \multirow[t]{2}{*}{0.4} & 0.67 & 0.12 & \multirow[t]{2}{*}{2.81} & \multirow[t]{2}{*}{0.007} \\
\hline & Group B & 0.16 & & 0.37 & 0.06 & & \\
\hline \multirow[t]{2}{*}{ Bhrama } & Group A & 0.03 & \multirow[t]{2}{*}{0.03} & 0.18 & 0.03 & \multirow[t]{2}{*}{1} & \multirow[t]{2}{*}{0.32} \\
\hline & Group B & 0 & & 0 & 0 & & \\
\hline \multirow[t]{2}{*}{ Apakti } & Group A & 0.53 & \multirow[t]{2}{*}{0.03} & 0.57 & 0.1 & \multirow[t]{2}{*}{0.22} & \multirow[t]{2}{*}{0.82} \\
\hline & Group B & 0.5 & & 0.57 & 0.1 & & \\
\hline
\end{tabular}

Table 4: Statistical Results While Comparing the Objective Parameters

\begin{tabular}{|l|l|l|l|l|l|l|}
\hline Groups & Mean & Deference in mean & \multicolumn{4}{l|}{ Unpaired test } \\
\cline { 4 - 7 } & & & SD & SE & ' $\mathrm{t}$ ' value & P value \\
\hline Group A & 4.66 & 0.4 & 2.98 & 0.54 & 0.44 & 0.657 \\
\hline Group B & 3.89 & & 3.89 & 0.71 & & \\
\hline
\end{tabular}

\section{Source of Support: Nil Conflict of Interest: None Declared}

How to cite this URL: Sabeena Susmitha A K \& Zenica D'souza: A Comparative Clinical Study To Evaluate The Efficacy Of Sankhapushpi Choorna With Sahapana Of Ksheera And Draksha Swarasa In Nidranasha w.s.r. To Primary Insomnia. International Ayurvedic Medical Journal $\quad$ online $\} 2020 \quad$ cited August, 2020 $\quad$ Available from: http://www.iamj.in/posts/images/upload/4058 4063.pdf 